\title{
Boals bildeteater som kroppslig utforskende refleksjon - En studie med næringslivsledere som forskningsdeltakere
}

\author{
Linda Wilhelmsen \\ UiT - Norges arktiske universitet
}

\begin{abstract}
Sammendrag
Artikkelen retter fokus på en fysisk teaterforms bidrag til kunnskapsproduksjon. Augusto Boals bildeteater er en dramafaglig arbeidsform og teaterform, som er inspirert av Paolo Freires kritiske pedagogikk med bruk av utforskende og kritisk refleksjon. Betydningen av denne kroppslige tilnærmingen og den kritiske refleksjonen undersøkes i denne studien. Det empiriske utgangspunktet for studien er et videreutdanningstilbud for næringslivsledere ved et norsk universitet, Bedriftskultur $i$ endring og utvikling, der bildeteater ble anvendt som kroppslig utforskende refleksjonsmetode. Studien er kvalitativ og materialet er generert gjennom intervju, observasjon, feltnotater og deltakernes evalueringer. Analysen viser at en kroppslig-affektiv ${ }^{1}$ og kognitiv gestaltning og kritisk refleksjon i bildeteater igangsetter transformative prosesser som kan bidra til nye måter å tenke på.
\end{abstract}

Nøkkelord: Bildeteater; kroppslig arbeidsform; kritisk refleksjon; transformasjon

\begin{abstract}
This article focuses on the contributions of a physical theatre form to knowledge production. Augusto Boal's image theatre is a dramatic work and expression form, based on Paolo Freire's critical pedagogy with use of explorative and critical reflection. The importance of the embodiment and the critical reflection is explored in this study. The empirical point of departure for the study is a further education course for leaders in the business sector, Corporate culture in change and development, offered at a Norwegian university, where image theatre was used as an embodied explorative reflection method. The study is qualitative and material is generated through interviews, observations, field notes, and participant evaluations. The analysis makes visible that an embodied-affective and cognitive critical reflection in image theatre initiates transformative processes that potentially contribute to new habits of mind.
\end{abstract}

${ }^{1}$ Affekt er en umiddelbar reaksjon, hva sansene forteller. Følelser består av affekter som deltakerne bearbeider i situasjonen. Se Tønnessen og Bjorvand (2014, s. 60f.)

^Korrespondanse: Linda Wilhelmsen, UiT Norges arktiske universitet, Postboks 6050 Langnes, 9037 Tromsø. Epost: linda.wilhelmsen@uit.no 


\section{L.Wilhelmsen}

Keywords: Image theatre; physical working form; critical reflection; transformation

Received: June, 2017; Accepted: May, 2018; Published: July, 2018

\section{Introduksjon}

Fysiske arbeidsformer innen drama- og teaterfaget, eksempelvis Augusto Boals bildeteater, omtales av Arne Engelstad som «generalprøve på virkeligheten» (Engelstad, 2001, s. 15). Problemstillinger og konfliktfylte situasjoner blir gjennom slike arbeidsformer iscenesatt og spilt ut i fiksjon, men med utgangspunkt i reelle konflikter deltakerne kan kjenne seg igjen i og identifisere seg med (Boal, 1985, s. 14). I videreutdanningstilbudet Bedriftskultur $i$ endring og utvikling for næringslivsledere i Nord-Norge, er kunstformen bildeteater anvendt som en kroppslig utforskende refleksjonsmetode for å belyse egenopplevde konfliktsituasjoner på arbeidsplassen. Under arbeidet med teaterformen gjør deltakerne seg erfaringer kroppslig-affektivt. Disse erfaringene setter i gang kognitive og emosjonelle prosesser i den deltakende gruppen (Engelstad, 2001).

I studien artikkelen bygger på, undersøker jeg deltakernes erfarte transformative prosesser med fokus på deres kroppslig-affektive og kognitive og kritiske refleksjon i og ute av fiksjon gjennom Boals teaterform bildeteater (Boal, 1985). Denne kroppslig-affektive dimensjonen har vært av interesse for min utforsking av problemstillingen: Hva betyr bildeteater som kroppslig-affektiv refleksjonsform for kursdeltakerne?

\section{Augusto Boal og De undertryktes teater}

Augusto Boal, brasiliansk teaterpedagog, teaterregissør, skuespiller og forfatter var aktiv i en politisk urolig tid i Sør-Amerika på 1970-tallet. Han var inspirert av pedagogen Paolo Freires arbeid for å fremme alfabetisme. Når folk kunne lese, kunne de ta del i samfunnet på mer informerte måter og protestere mot fortrykk. Folk ble undertrykket av styringsmaktene og led under de dårlige levevilkår de ble påtvunget. Freires frigjørende pedagogikk beskriver to stadier i en utviklingsprosess fra undertrykkelse til frigjøring; 1) de undertrykte avslører den verden av undertrykkelse de lever i, 2) gjennom praksis engasjerer de seg i omforming av den (Freire, 1968/2011, s. 37). Boal og Freire var store inspiratorer for hverandre i deres utrettelige arbeid mot myndighetenes undertrykkelse av folket i Sør-Amerika. Begge utga bøker: De undertryktes teater (Boal, 1979) respektive De undertryktes pedagogikk (Freire, 1968/2011). Freires beskrivelse av utviklingsprosessen fra undertrykkelse til frigjøring er en parallell beskrivelse av Boals teaterteknikker.

Boal mente at teater kan fungere som et politisk verktøy, og utviklet teaterformene og metodene til De undertryktes teater for å gi det undertrykte folket en metode for å bryte undertrykkelsene det politiske maktapparatet påførte dem. Teaterformene hadde til hensikt å gi folket økt forståelse for de overgrep de var utsatt for, og økt 
bevissthet om hva og hvordan de skulle bryte undertrykkelse ved å endre sin atferd og handling. Arbeidsformen bildeteater er en kunstform med en klar dramaturgisk oppbygning der aktørene er skuespillere og agerer i roller i tablåene. Den fungerer som en kritisk refleksjon der deltakere gjennomgår en pedagogisk endrings- og utviklingsprosess. Undertrykkelsen i Boals Sør-Amerika var brutal og sterkt politisk. På tross av åpenbare forskjeller mellom nordisk demokrati og forhold i Sør-Amerika har Boals teater for sosial forandring ${ }^{2}$ vunnet innpass i Norden. Undertrykkelsen som undersøkes har da i nordisk kontekst vært mer psykologisk enn politisk.

\section{Bildeteater som arbeidsform}

I bildeteater er alle deltagende som skuespillere, observatører og medspillere. Teaterformene legger opp til «... å se seg selv» (Boal, 2003, s. 12):

[Den] er en form for viden. Det kan og bør også være et middel for at ændre samfundet. Teatret kan hjælpe os at bygge fremtiden fremfor blot at vente på den.

(s. 13)

Problemstillinger og konfliktfylte situasjoner blir iscenesatt og spilt ut i fiksjon, men med utgangspunkt i reelle konflikter deltakerne kan kjenne seg igjen i og identifisere seg med (Boal, 1985, s. 14). Teaterformen gir mulighet til å granske reelle, dog iscenesatte konfliktsituasjoner der den kritisk-refleksive granskningen kan bidra til endrings- og utviklingsprosesser (Boal, 1985; Freire, 1968/2011). Den kritiske refleksjonen kan være et betydningsfullt bidrag til en nødvendig nyansering av problemstillinger, oppfatninger og opplevelser, som i utgangspunktet er emosjonelle og subjektive. Den metodiske prosessen foregår gjennom å forme personer inn $\mathrm{i}$ 《fryste» bilder. Det lages en bildeserie som viser bilder fra en konfliktfylt situasjon til en løsning, altså en ideell situasjon. Metodene i De undertryktes teater har sine regler, men Boal sier de ikke er fastlåste oppskrifter som må følges til punkt og prikke (Boal, 2003, s. 174, 233). De kan tilpasses gruppene, tematikk og målet, men de har noen viktige prinsipper som ikke kan endres: «Medspillerne skal være hovedpersoner i den dramatiske handlingen, og disse medspillerne skal forberede sig til at være hovedperson i deres eget liv» (Boal, 2003, s. 252). Målet er at løsningene/handlingsalternativene kan ha overføringsverdi til liknende situasjoner, og at den dyptgående refleksjonen som skjer underveis i spillets gang, kan bidra til økt bevissthet og innsikt, noe bruken av bildeteater i endrings- og utviklingsprosesser i studiet Bedriftskultur $i$ endring og utvikling hadde som hensikt.

Arbeidet med bildeteater tar utgangspunkt i konkrete konflikter hver enkelt student har opplevd eller står i - konfliktene er en del av deres liv. Hensikten er å utforske

${ }^{2}$ I1994 fikk Augusto Boals teaterteknikker en offisiell anerkjennelse av UNESCO som «A tool for social change». 


\section{Wilhelmsen}

flere handlingsalternativer og søke løsning på den undertrykkende konflikten. Prosessen med bildeteater foregår som følger:

1. Konflikttema: Gruppen deles inn i mindre grupper og enes om en av konfliktene.

2. Første tablå, konfliktbildet: Gruppen lager et bilde som viser kjernen av konflikten der personer settes inn $\mathrm{i}$ "fryste» posisjoner. Bildet viser en situasjon der undertrykkelsen er et faktum.

3. Scenografi: Det settes opp et spillerom med enkel scenografi som illustrerer det faktiske rommet eller miljøet konflikten utarter seg i. Det kan være en illustrasjon av et typisk miljø (arbeidsplass, skolegård, pauserom, etc.).

4. Andre tablå, idealbildet: Gruppen lager et bilde som viser hvordan de mener situasjonen ideelt sett skal være - et idealbilde.

5. Tredje tablå, løsningsbildet: Det mest utfordrende bilde å lage er bildet mellom konfliktbildet og idealbildet. Dette skal vise en realistisk vei ut av konflikten, en løsning som realistisk sett skal være mulig å gjennomføre - løsningsbildet. Det kan lages flere bilder som viser ulike veier fra konflikt til idealsituasjon.

6. Fremvisning og refleksjon: gruppen viser hele bildeserien fra konflikt til idealbilde for de andre gruppene. Kritisk refleksjon om enkeltpersoners handlinger, intensjoner og hensikter i bildene gjennomføres av alle.

Bildeserien blir fremstilt i en bestemt rekkefølge; bilde 1, bilde 3 og til slutt bilde 2, altså idealbildet som viser hvordan man ønsker at situasjonen skal være ideelt sett, dog realistisk. At rekkefølgen på arbeidet med bildene ikke følger en 1-2-3 serie, men 1-3-2, tar utgangspunkt $\mathrm{i}$ at konflikten er et faktum, man lager et bilde som viser konfliktens kjerne. Neste steg er å reflektere over hvordan man ideelt sett ønsker det skal være. Disse to bildene er de to «enkle» bildene å lage, mens det tredje bildet, den realistiske veien mellom «krig og fred» er betydelig vanskeligere. Her kreves den dyptgående refleksjonen over konflikten og idealsituasjonens enkeltbestanddeler.

\section{Metode}

\section{Studiens kontekst og deltakere}

Studenten sitter på kanten av et bord litt fremoverlent med benene hengende rett ned. Ryggen er lett krum og ansiktet ligger $i$ alvorlige folder. «Dette ble sterkt», sier hun. Feg lurer ei stund på om tårene hennes vil komme. Hele studentgruppen sitter eller står rundt omkring $i$ rommet med oppmerksomheten rettet mot henne. De er alle alvorlige og tause. Vi er akkurat ferdige med en arbeidsøkt med bildeteater - en fysisk teatermetode, og vi har jobbet med hennes konflikt, en konflikt hun har hatt over lang tid med en kollega på sin arbeidsplass.

(Narrativ vignett 1; forskerens feltnotat)

Fortellingen er en faktisk hendelse fra et undervisningsopplegg i videreutdanningstilbudet Bedriftskultur $i$ endring og utvikling. ${ }^{3}$ Samtlige studenter er ledere eller

${ }^{3}$ Se også Wilhelmsen, 2010 og 2017. 
mellomledere $\mathrm{i}$ en bedrift, eller nøkkelpersoner med lederoppgaver. Studentene jobber med konkrete konflikter de er involvert i gjennom personlig fortelling, tablå og bildeteater (Boal, 2003). Studiet ble utviklet i samarbeid med sentrale næringslivsaktører i Nord-Norge, og hadde fokus på organisasjonskultur. Målet var å øke bevisstheten om bedriftskultur og dens betydning for utvikling og lønnsomhet i en organisasjon. Arbeidsmiljøet i de aktuelle bedriftene var preget av høyt sykefravær og stor grad av mistillit til ledelse og hverandre. Det var i liten grad involvering og inkludering i utvikling av bedriften, og den vektlagte styringsformen hadde mål om økonomisk forbedring gjennom strategi, struktur og systemer. Næringslivsaktørene som ønsket dette videreutdanningstilbudet anså det som et stort behov å utvikle ledernes endringskompetanse for nettopp å gjøre dem bedre i stand til å lede endringsprosesser. Av de 30 studiepoeng kurset omfattet ble omtrent 1/3 del av tiden brukt på bildeteater og andre teaterformer. I denne artikkelen er arbeidet med bildeteater i fokus.

Til sammen 20 ledere fra ulike organisasjoner i Norge utgjorde studentgruppen hvert år. Studiet ble gjennomført tre ganger i perioden 2007-2009. Studiet var samlingsbasert over ett år. Som forskningsdeltakere deltar ni av studentene, tre fra hver av gruppene.

\section{Avgrensning og forskerposisjon}

Studien er avgrenset til en multippel kasusstudie. Studien er en liten kasusstudie, intervjumaterialet er basert på få informanter, kun 9 av ca. 60 studenter over 3 år, noe som er for lite til å generalisere resultatene (Andersen, 1997). Divergerende meninger og opplevelser fra de andre studentene er ikke kommet frem. Feltnotater fra plenumsrefleksjoner og evalueringer viser ingen motforestillinger, men er heller en bekreftelse på funnene. Det betyr ikke at ingen av de andre studentene på studiet hadde andre opplevelser, men disse har ikke kommet frem gjennom de forskningsmetodene jeg har lagt opp til. Gjennom undersøkelsen søker jeg forstå og avdekke hvordan en kroppslig-affektiv arbeidsform som bildeteater kan produsere ny kunnskap gjennom utforskende refleksjon. Samtidigheten i den kroppslige og verbale refleksjonen under en bildeteatersekvens forstås som en måte å søke forståelse av alle bestanddeler i en konfliktsituasjon både kroppslig-affektivt og kognitivt. Det affektive omfatter de kroppslige fornemmelser som deltakerne erfarer som ulike affekter, eller som følelser som vekkes. Kritisk utforskende refleksjon gjennom kunstformen bildeteater omfatter holdninger, verdier, situasjonsbetingede forhold, moral og normer.

Jeg har en dobbel rolle i dette prosjektet, dels som underviser og den som har utviklet prosjektet, samt som aktiv tilrettelegger og observatør i plenums- og gruppevise refleksjoner og evalueringer, og dels som forsker på deltakeres erfaring av min undervisning. Mangel på distanse kan være en svakhet ved studien, men som et eksempel på mulig tillempning av kritisk pedagogisk tenkning i kunstpedagogisk arbeid basert på Boals teaterfilosofi, kan denne studien allikevel være et bidrag. 


\section{L.Wilhelmsen}

\section{Måter materialet er generert på}

Undersøkelsen er basert på kvalitative metoder for datainnsamling som semistrukturerte intervjuer (Justesen \& Mik-Meyer, 2010, s. 55), deltakende observasjon og forskerens feltnotater, underveis i studiet Bedriftskultur $i$ endring og utvikling. Feltnotatene ble gjort etter observasjonene av samlingene, i de gruppevise refleksjoner underveis og i etterkant av arbeid med bildeteater i tre ulike studentkull. Forskerens feltnotater omfatter 112 sider. Tre studenter fra hvert kull ble i tillegg intervjuet. Utvalget ble gjort gjennom forespørsel i plenum, og de tre første i hvert kull som meldte seg ble valgt. Intervjuene er semistrukturerte (Justesen \& Mik-Meyer, 2010) og varer mellom 32 og 56 minutter. De ble tatt opp med diktafon og transkribert. Intervjutekstene utgjør til sammen 91 sider. Spørsmålene i intervjuene dreide seg om deltakernes egne opplevelser før, underveis og etter bildeteatersekvensen, emosjonelt og intellektuelt. Intervjuene ble giennomført etter studieslutt hvert år, og fungerte også som studentevalueringer.

Kvale og Brinkmann (2010, s. 22) definerer intervju som en utveksling mellom to personer som samtaler om et tema av felles interesse. Det er en profesjonell samtale som krever tillit mellom partene og balanse mellom en tillitsfull relasjon og en kunnskapsproduksjon (Kvale \& Brinkmann, 2010). Intervjusvarene ble sortert etter et temporalitetsprinsipp med fokus på hvordan deltakerne tenkte før, under og etter arbeidsprosessen. (Czarniawska, 2004, s. 83). Målet med intervjuene er å finne ut hva studentene forteller om egne konflikter og hvordan de forholder seg til disse før arbeidsmetoden bildeteater, hvordan de opplever det underveis i arbeidet - emosjonelt og intellektuelt, og hva de opplever og erfarer i etterkant av denne arbeidsformen med personlige konfliktfortellinger.

\section{Analysemåter i denne studien}

Analysen er delvis teoridrevet gjennom at Argyris modell for dobbeltkretslæring adapteres for denne analysen. I tillegg er Wackerhausens refleksjonsmodell for refleksjon $i$ andre ordningens perspektiv, brukt som tankemodell. Som læringsteori bruker jeg tankegods fra Mezirows transformative læringsteori. Disse teoriene presenteres i følgende avsnitt som studiens teoretiske forståelsesbakgrunn, og de gir samtidig teoretiske begreper for analysen som har en abduktiv forskningslogikk.

Analysen har også en praksisnær dimensjon giennom beskrivelse av forløp i studiet og gjennom rik illustrasjon av deltakernes erfaringer av bildeteaterarbeidet, slik de ser på det ved studiets begynnelse, under forløpene og i etterkant av øktene med bildeteater.

\section{Teoretisk forståelsesbakgrunn}

Boal hevder at et forløp i de undertryktes teater aldri slutter. Selv om man finner løsning på en konflikt i ett forløp, vil det ikke nødvendigvis være løsningen for andre i en liknende konflikt. Det er avhengig av de til enhver tid indre og ytre omstendigheters 
påvirkning. Målet med teatermetodene er «... at opmuntre til autonom handling, at sætte en proces i gang, at stimulere transformativ kreativitet, at skabe tilskuere om til hovedpersoner» (Boal, 2003, s. 255-256). I den teoretiske forståelsesbakgrunn jeg skisserer for studiens utforsking, bygger jeg på Argyris tanke om dobbeltkretslæring, Wackerhausens refleksjon i andre ordningens perspektiv og Mezirows transformative læringsteori.

\section{Bildeteatrets læringsrom som eksempel på dobbeltkretslæring}

Argyris (1992) modell for enkel- og dobbeltkretslæring belyser to læringsprosesser; 1) problemløsing ('single-loop learning'), og 2) verdi-basert læring ('double-loop learning'). For å oppnå faktisk endring må man helt tilbake til de grunnleggende verdiene, troen og rammevilkårene for ens målsetting og gjøre en vurdering og granskning av disse. Argyris fremmer 'double-loop'- læring som den viktigste for varig endring og utvikling. Jeg har gjort en adaptasjon av Argyris modell (vist i figur 1), der arbeidsprosessen med bildeteater granskes og de styrende variablene i en konfliktsituasjon avdekkes (figur 1). I denne studien blir organisasjonens verdier, mål og rammebetingelser vurdert og reflektert over. En 'double-loop' blir gjennomført $\mathrm{i}$ arbeidsprosessen med bildeteater der holdninger, verdier og mål blir undersøkt og analysert.
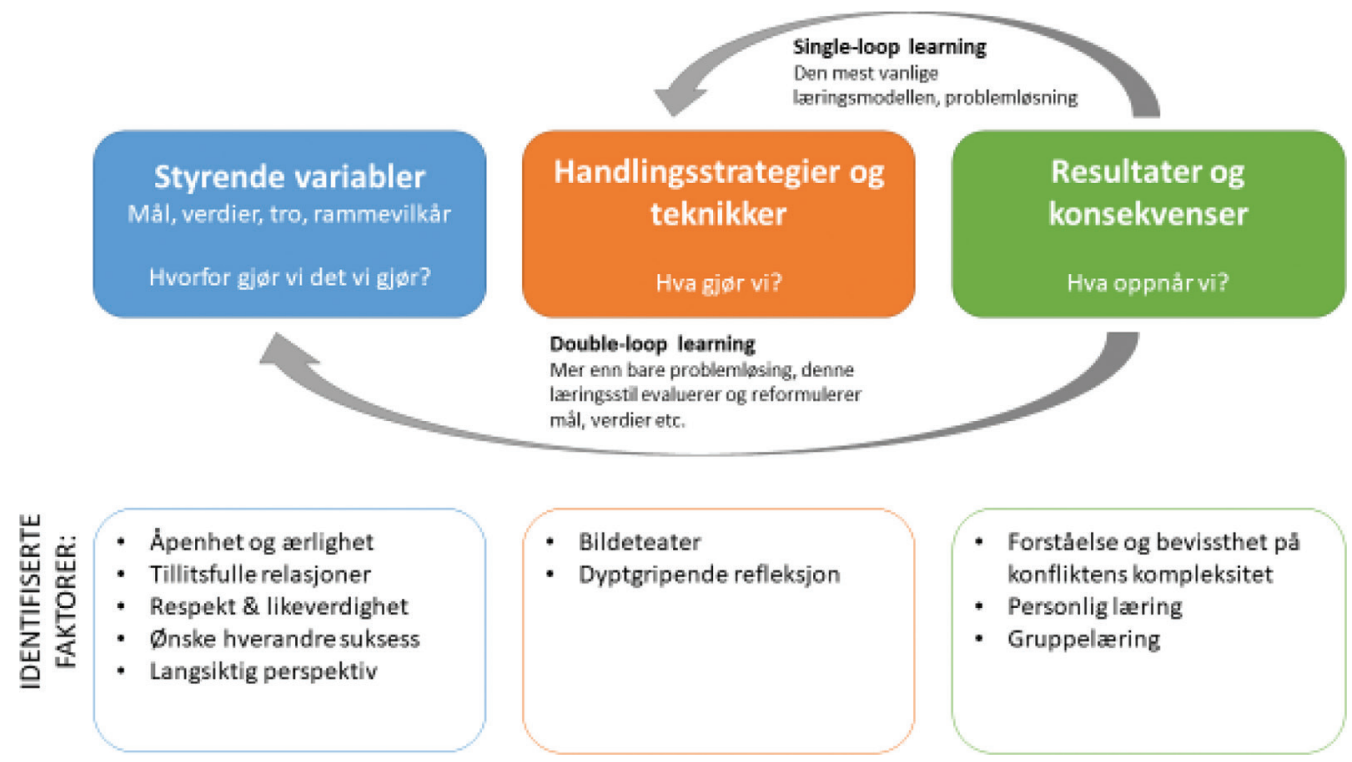

- Bildeteater

- Dyptgripende refleksjon
- Forstảelse og bevissthet pă konfliktens kompleksitet

- Personlig læering

- Gruppelæring

Figur 1. Modell for enkel- og dobbeltkretslæring gjennom bildeteater (adaptasjon av Argyris modell, 2018).

Avgiørende forhold for økt forståelse og bevissthet, erkjennelse og mulig læring, er å søke svar på hvorfor vi gjør det vi gjør, slik både Argyris og Boal løfter frem. Begge 


\section{L.Wilhelmsen}

hevder at det må grundig utforsking av grunnleggende verdier for å komme til neste steg i en læringsprosess, nemlig hva gjør vi, for så å kunne analysere hva vi har oppnådd. Hvis det vi oppnår ikke er ønskelig, ikke er realistisk eller ikke gir et positivt resultat, giør vi prosessen på nytt - en 'double loop'.

Bildeteatrets arbeidsform har som fokus å belyse flere sider av konflikten for å danne et mer helhetlig bilde av situasjonen og dens indre og ytre omstendigheter. Gjennom de aktive rollene deltakere har i bildeteater, ligger muligheten for å frigiøre seg fra etablerte antakelser, forståelser og fordommer som snevrer ens forståelse og opplevelse av konflikten og den undertrykkende situasjonen. Fortellingen forandrer seg bokstavelig talt gjennom de endringene og omformingene aktørene gjør med tablåene. Man analyserer konfliktens kompleksitet, skaper en syntese gjennom å foreslå et idealbilde - en løsning på konflikten, det blir en abstraksjon av ens indre forståelse. Man generaliserer den personlige konfliktopplevelsen til en allmenn konfliktopplevelse, noe alle kan oppleve å komme i. Bildeteater utforsker ulike løsningsforslag som har en overføringsverdi til andre type konflikter. Generaliseringen kommer tilbake til aktøren som eier konflikten som en ny forståelse og kunnskap, som kan bidra til de valg denne gjør for fremtiden.

Den fysisk utforskende refleksjon - refleksjon i andre ordningens perspektiv skriver Wackerhausen (2015) i Erfaringsrom, handlingsbåren kunnskap og refleksjon om refleksjon som «... en nødvendig og uerstattelig læremester, ... men ikke alltid troverdig» (s. 81). Han demaskerer tre ulike erfaringsformer som kan bedra mennesker i troen på en god og konstruktiv erfaring; selvbekreftende erfaring, beskyttende erfaring og selektiv erfaring. Demaskeringen av bedragene skjer gjennom refleksjon av 2. orden. Han sier det er nødvendig med "... en konstruktiv fremmedgjørelse av sedvane» - en refleksiv analyse, refleksjon i 2 . orden (s. 81). Denne særlige form for refleksiv analyse krever «... ressurser som skal hentes i "fremmed landskap", det vil si fra fremmede teorier, fremmede erfaringsrom og fremmede profesjoner» (Wackerhausen, 2015, s. 81), noe bildeteater etter mitt syn kan sies å giøre. Han løfter frem et viktig perspektiv om erfaring som «blind førermester», der erfaringsrom ikke nødvendigvis giør oppmerksom på egen feilaktighet.

Teaterformene ${ }^{4}$ i De undertryktes teater (Engelstad, 2001) analyserer problemer, situasjoner, tilstander og konflikter gjennom fysisk sansende og dyptgripende utforsking. Man bringer inn synspunkter og ressurser fra det Wackerhausen kaller «fremmed landskap» hvor teorier, erfaringer og profesjoner fra andre fagområder retter et refleksivt blikk på fenomenet. Bildeteater vil i så måte være en fremmed profesjon som gjennom sin metodiske refleksjonsform, bringer nye perspektiver og erkjennelser frem. Det kan fremstå som en konstruktiv fremmedgiørelse av sedvane, som bringer ny og utvidet forståelse for problematikken giennom sin fysiske sansende form.

\footnotetext{
${ }^{4}$ Augusto Boal utviklet flere teaterformer enn den formen som brukes i denne studien - bildeteater. Blant andre forumteater og Rainbow of desire.
} 
For de involverte i arbeidet med denne metoden vil en økt bevissthet på nettopp en konflikts kompleksitet kunne bidra til endringer av egne holdninger og verdier - og bidra konstruktivt i læringsprosesser. Jeg ser på Wackerhausens begrep av refleksjon i 2. orden som et bilde på den kroppslig-affektive utforskende refleksjonsformen Boal har utviklet gjennom sine teaterformer.

\section{Voksnes transformative læring etter Mezirow}

Mezirow (2007) har siden 1970-tallet arbeidet med å utvikle en transformativ læringsteori. Denne teorien kan plasseres inn under den kritiske teoriparaplyen. Han ser for seg 'disorienting dilemmas' som startpunkt for transformative læringsprosesser, når et individs tenkemåter og handlinger ikke lenger fungerer $\mathrm{i}$ det sosiale samspillet. Han tenker seg ulike stadier av transformasjon, fra å justere referanserammer, bytte ut referanserammer med nye, forflytte seg slik at man ser andre perspektiver og til slutt er det mulig å ha erobret nye måter å tenke på. I Norden har Illeris (2013) videreutviklet Mezirows teori om transformativ læring, og han skriver at når man kommer inn $\mathrm{i}$ en transformativ læringsprosess er den ofte konfliktfylt og kan oppleves som en krise, men når man kommer igjennom oppleves det som en ny identitet hos den voksne. Dette samsvarer med arbeidsprosessen i bildeteater.

\section{Studentenes fortellinger om erfaringer av arbeid med bildeteater}

\section{Arbeidsprosessen}

Studentene ble delt inn i grupper á fire. De fortalte etter tur om egne konflikter. Gruppene valgte én av konfliktene å jobbe i fellesskap med. Den som eide opplevelsen, forklarte konfliktens bestanddeler, hvilke roller de ulike personene $\mathrm{i}$ tablået har, hvilke relasjoner de har til hverandre og hva utfordringen består av. Hver gruppe utarbeidet en bildeserie og viste den for storgruppen. Bildeserien skal vise endringer fra konflikt til en ideell situasjon, men endringer i bildene fra konflikt til løsning må være realistisk for å kunne fremstå troverdig (Boal, 2003, s. 174). Tablåer som viser en urealistisk situasjon vil Boal kalle 'magisk', altså ikke realistisk, og dermed ikke aktuell i et slikt arbeid som søker realistiske løsninger på reelle konflikter (Engelstad, 2001, s. 56). Erfaring fra denne og andre prosesser med bildeteater viser at urealistiske forslag til løsning fører ingen steds hen, men kan spre motløshet i gruppen, da det antyder at det ikke finnes en realistisk løsning på problemet. Det blir en "deus ex machina", en magisk hendelse eller person som plutselig dukker opp og løser problemet (Platz-Waury, 1992, s. 150), og fremstår dermed urealistisk. Konflikten og undertrykkelsen består, og alvoret i situasjonen og arbeidsprosessen blir forvitret og nedgradert. Avkledningen av skjulte hensikter og motiver, er en effekt av arbeidsformen, som legger til rette for ærlighet og et større sannferdig bilde av situasjonen. 


\section{Wilhelmsen}

\section{Refleksjoner ved studiets begynnelse}

Funnene i denne studien viser at studentenes fortellinger om situasjonen før arbeidsprosessen med bildeteater, var at den var preget av opplevelser av å bære på en ubearbeidet konflikt som påvirket deres hverdag negativt, på jobb og ellers i livet. Opplevelse av undertrykkelse ga dem dårligere selvbilde og mindre tro på seg selv. De følte seg ikke tatt på alvor og ble ikke sett eller hørt. De mistet etter hvert tillit til sine kolleger og ledere, som gikk ut over trygghetsfølelsen. De ble usikre på seg selv og på sin verdi og betydning for de nære omgivelsene. De tenkte negative tanker om seg selv, og mistrivdes på jobb. De fortalte om lavere motivasjon og yteevne, og de opplevde at de ikke klarte å ta ut det potensial de mente de hadde i seg.

Det syns jeg var vanskelig først, fordi de fortellingene jeg da hadde ble ikke tatt på alvor.

(Sitat 1 , studentintervju)

Feg syns man er for lite raus med hverandre ... og har en litt forutinntatt holdning om hvordan den andre er.

(Sitat 2, studentintervju)

\section{Refleksjoner underveis i prosessen med bildeteater}

Underveis i arbeidsprosessen, når deltakerne jobbet konkret med bildeteater, fortalte samtlige ni intervjuede studenter om sterke emosjonelle opplevelser. I arbeidet der medstudenter var til stede og hadde oppmerksomhet og fokus på deres arbeid, opplevde mange for første gang å bli lyttet til og tatt på alvor. De opplevde sine medstudenter i gruppene som lyttende og genuint interessert og oppmerksomme på deres problemstilling, og en forløsning av innestengte vonde følelser som satte sterke følelser i sving:

Det her var fysisk, det var de andre sine hender som hjalp meg ut av det.

(Sitat 3, studentintervju)

$N a ̊$ vil jeg bare hjem og legge meg under et pledd på sofaen og prøve å fordøye de inntrykk og innspillene jeg har fått. Feg føler meg mentalt og fysisk sliten. (Sitat 4, studentintervju)

\section{Refleksjoner i etterkant av prosessen med bildeteater}

Etter arbeidsprosessen løftet studentene frem betydningen av å ha vært gjennom bearbeiding av sine konflikter i gruppene. Opplevelsen var entydig positiv, ingen av mine informanter, heller ikke de studentene jeg hadde samtale med underveis i studiet og i ettertid, ga uttrykk for en negativ opplevelse av denne arbeidsformen. De sier de følte en stor lettelse. Det fikk positive ringvirkninger på det personlige plan, de fikk følelsen av å bli trodd, og fikk hjelp gjennom åpne, veiledende spørsmål fra gruppemedlemmene til å komme nærmere en løsning. De fortalte at de satt med en følelse av å ha fått troen på seg selv igjen, en følelse av å være betydningsfull. Studentene opplevde økt motivasjon og kraft til å gi av seg selv, ytelsen økte både i vilje og evne og satte bearbeidingen av denne konflikten inn i en større sammenheng med andre viktige aspekter av livet sitt. Studentene utviklet et historisk perspektiv, 
et kompetanseperspektiv og et personlig perspektiv på hva det betydde for dem å fortelle, for deres egen mentale helse og for forståelsen av seg selv som en positiv bidragsyter i fellesskapet:

... det er som det gikk hull på en vond byll.

Det er første gang jeg føler meg sett og hørt.

Du skapte på en måte et rom der, et trygt rom å gå inn $i$ og vi gled rett inn $i$ cerligheten.

(Sitat 7, studentintervju)

For meg så er det litt sånn FØR og ETTER ... på mange måter. Det skjedde noe i meg og med meg.

(Sitat 8, studentintervju)

Det opplevdes som skjellsettende for meg, jeg tenker annerledes om situasjonen, meg selv og den andre nå.

(Sitat 9, studentintervju)

Det studentene forteller om kan beskrives som transformative læringsprosesser, som ga disse studentene nye måter å tenke på og dermed også ny identitet. I de neste avsnittene drøfter jeg mulig betydning av funnene.

\section{På vei mot ny erkjennelse og kunnskap gjennom utforskende refleksjon}

Gjennom arbeidsformen med bildeteater opplevde studentene en dyptgripende refleksjon som ga dem utvidet forståelse av en konflikts kompleksitet, en refleksjon i 2. orden (Wackerhausen, 2015, s. 97). Det fysiske arbeidet gjennom bruk av egen og andres kropper i utforming av tablåer, samt den dialogiske refleksionen underveis i arbeidet, utfordret sider av studentenes konflikter og organisatoriske utfordringer som en teoretisk, boklig refleksjon og lærdom ikke kan berøre. De opplevde at den kroppslige opplevelsen og erfaringen man oppnår gjennom kunstformen bildeteater, ga dem et mer helhetlig bilde av de sammensatte utfordringene. Dette arbeidet kan ses som en dobbeltkretslæringsprosess, der den kroppslig-affektive refleksjonen og den kritiske verbale refleksjonen støttet opp om transformative prosesser av betydning for deltakerne.

Koblingen mellom teori og praktisk arbeidsform ga dem en dypere forståelse av situasjonene enn om bare en av disse kunnskapsformene skulle få råde grunnen alene. Wackerhausen hevder at «... et samspill mellom akademisk og praktisk kunnskap, en anerkjennelse av at erfaring uten refleksjon er blind, og refleksjon uten erfaring er tom» (Wackerhausen, 2015, s. 99). Den utforskende refleksjonen påvirker forståelsen av relasjoner og konflikters kompleksitet. Gjennom bildeteaterets utforskende arbeidsform kom mange synspunkter og oppfatninger av konflikten frem. Det ble gjennomført en kritisk og konstruktiv refleksjon ved at hver enkelt fikk utfordret sitt forslag gjennom andres reaksjoner og forslag.

feg fikk en følelse av veldig sterkt samhold ... fordi vi tolket oss inn i historien, situasjonen og vi bestemte en del premisser. A få bildene så klart fremstilt, situasjonen belyst så klart, 


\section{L.Wilhelmsen}

syns jeg ble en veldig effektiv måte å ta stilling til og behandle. Den innsikten vi fikk, både den saklige og relasjonelle, opplevde jeg som veldig nyttig.

(Sitat 10, student)

Studentene fortalte at de ved å forme andres kropper inn i nye posisjoner, fikk tydeliggjort holdninger, verdier og motiver, og de opplevde at det de uttrykte satte spor både i dem som ble formet, men også i dem selv. Når de satte tanker på personene i tablået, var det en måte å gi til kjenne egne holdninger, verdier og motiver. Det opplevdes som utfordrende, dog positivt å være så ærlig i utforskingen både av det som skjer utenfor en selv, men også det som er «inne i en selv». (sitat student). Nettopp "det nye» ga rom for nye emosjonelle opplevelser, erkjennelser og erfaringer (Boal, 2003, s. 53). Studentenes individuelle problemer ble vurdert og tolket av andre. I den kritiske og utforskende refleksjonen ble de bevisst sin egen subjektive fortolkning og forståelse, og de ble altså bevisstgjort sin egen tilkortkommenhet. Men i det trygge og ærlige rommet de opplevde å være i, opplevde de også «demaskeringen» som et konstruktivt bidrag til en mulig løsning av konflikten og personlige utvikling.

feg har fått andre ... hva skal jeg si-perspektiver, men også andre plattformer å stå på som leder. Feg ser ting fra flere sider, og trekker meg litt mer tilbake og reflekterer litt mer. Det har ført til at jeg har blitt mer bevisst på de valg jeg tar.

(Sitat 11, student)

Den personlige konfliktfortellingen ble ikke et speilbilde av noe, men gjenspeiler noe (Methi, 2015, s. 131). Studenten har vært i en prosess der hen har stått i et sterkt førstepersonsperspektiv og blottstilt sin innerste private sfære (Methi, 2015, s. 131). Den er utforsket av hele gruppen som har bearbeidet, omformet og reflektert over relasjonene mellom henne og hennes kollega, over konfliktens innhold, begges sider av den, rammeforholdene rundt dem (som 'styrende variabler' i Argyris' læringsmodell), holdninger og verdier til begge parter, og endrings- og utviklingsmuligheter - for dem begge. Studentene beskrev dette som en erkjennelsesprosess som har gjennomgått en kollektiv undersøkelse, der ny innsikt og kunnskap ble etablert hos den som eide konflikten, men også i resten av gruppen som fikk gjennomgått en undersøkelse av egne holdninger, tanker og verdier i arbeidsprosessen. Det førte til en frigjørende prosess som distanserte tanken og opplevelsen fra å være en ren subjektiv indre forståelse til å bli en offentliggjort tanke og opplevelse.

Den ga meg mulighet til refleksjon fordi jeg fikk ting mer på avstand og så nye perspektiver. feg fikk bearbeidet sterke følelser jeg hadde knyttet til den negative situasjonen, og refleksjonen og avstanden til situasjonen gjorde at den ble satt $i$ et mer objektivt perspektiv.

(Sitat 12, student)

Distansen denne fremmedgiøringen og frigjøringen forårsaket, ga rom for endringer av egen subjektiv, indre forståelse, og ble en skapelsesprosess i et dialektisk forhold; en forandring fra noe som var til noe som blir, og «tanken kom tilbake som forandret, og det bidro til et 'forandret selv'" (Methi, 2015, s. 144). 


\section{Fra undertrykkelsen til endring}

I følge Freire (1968/2011) vil sann refleksjon, og en kritisk og frigjørende dialog kunne føre til handling og endret praksis. Gjennom de undertryktes pedagogikk «... avslører de undertrykte den verden av undertrykkelse de lever i og gjennom praksis engasjerer de seg i omforming av den.» (Freire, 1968/2011, s. 37). Freire frigjørende pedagogikk løfter frem likeverdighet i fellesskap der dialogen er et viktig verktøy for å forløse menneskets rike muligheter (Freire, 2011, s. 13). En av de viktigste faktorene i dialogen er lytteegenskapen (Bohm, 2010). I bildeteater som arbeidsform arbeidet deltakerne med dialogen gjennom vekslende innspill ved å endre fysisk på tablåene. På den måten «tvinges» deltakerne til å lytte, til å ta inn andres tolkninger og innspill til den undertrykte situasjonen.

En positiv ringvirkning av denne utforskende arbeidsformen kan være dens bidrag til utvikling av personlige egenskaper, som gjør deltakerne bedre i stand til å dekode andres motiver og motivasjoner. Man søker å forstå alle de involverte i sine motiver, tanker og følelser. «For å overvinne undertrykkelsen må mennesker først bli klar over dens årsaker, slik at de ved å handle annerledes kan skape en ny situasjon» (Freire, 1968/2011, s. 28). De store spørsmål blir HVA, HVORFOR, HVORDAN og HVEM; hva skjer? hvorfor skjer det? hvordan kan vi endre? og hvem er jeg og den andre i dette bildet? Jeg har visualisert stadiene i utviklings- og endringsprosessen i figur 2.

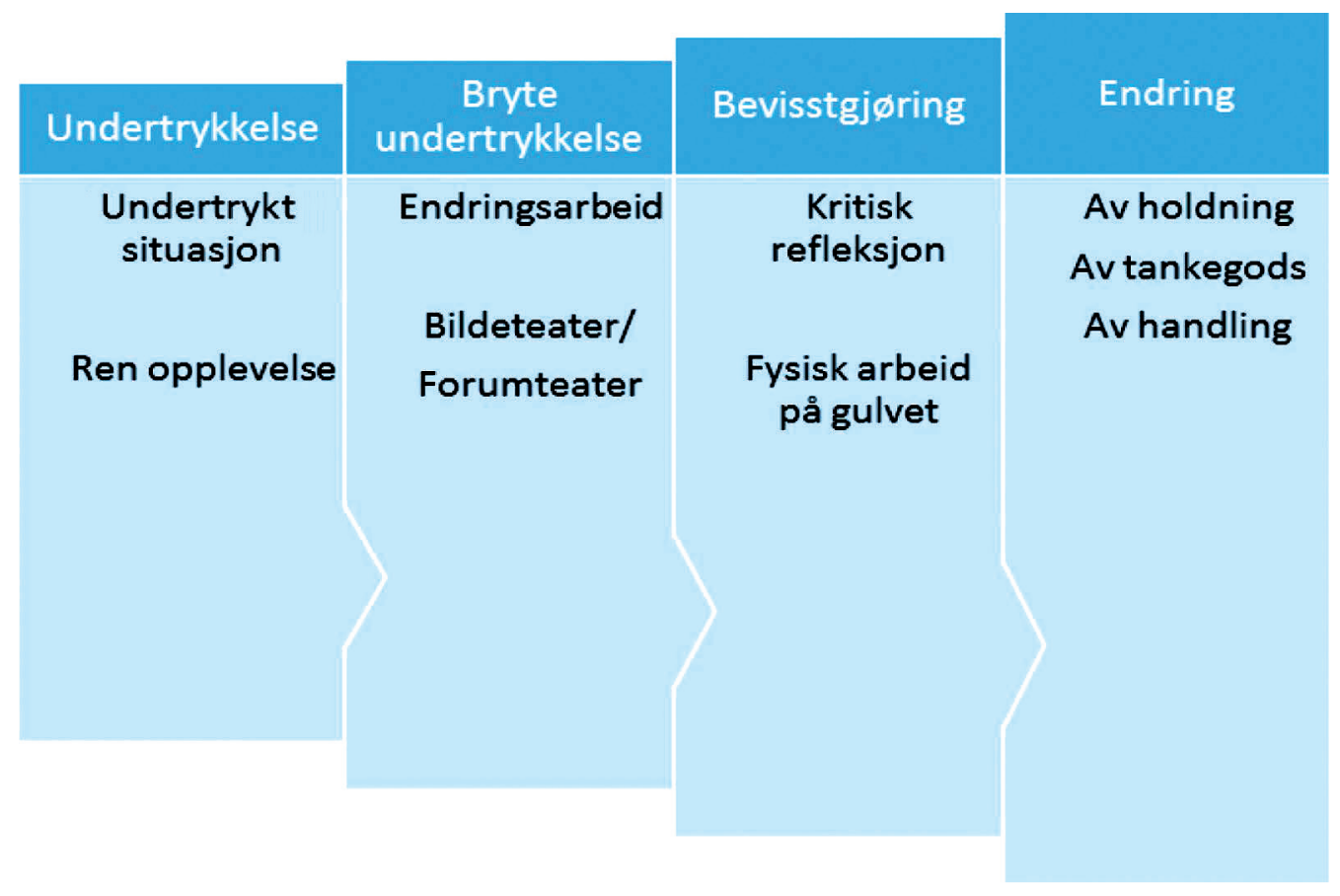

Figur 2: Utviklingsprosess i bildeteater. 


\section{Wilhelmsen}

Den utdypende refleksjonen gjennom bildeteater vil bidra til å løse opp i de selvbedrag det selvbekreftende, beskyttende og selektive erfaringsrommet ofte fører individer inn i. Som Wackerhausen sier er «... erfaring en nødvendig og uerstattelig læremester, ... men ikke alltid troverdig» (Wackerhausen, 2015, s. 81). Den erfaringsbårne kunnskapen kan være basert på et selvbedrag som former ens tanker og holdninger, og som igjen påvirker ens valg og handlinger. Å bli bevisst sine - og andres - «selvbedrag», fører til en utvidet forståelse og bevissthet for tingenes tilstand, noe som bidrar til utvikling av en selv.

\section{Avslutning}

$\AA ̊$ arbeide med Boals teaterformer der hver øvelse er «... en fysisk reflektion af en selv» (Boal, 2003, s. 73), ga de fleste deltakerne en opplevelse av forløsning, de følte seg sett, hørt, og forstått. Det er "A tool for social change» (Engelstad, 2001, s. 15). Som en av studentene sa: «Du skapte på en måte et rom der, et trygt rom å gå inn i, og vi gled rett inn i ærligheten».

Den utforskende og kritiske refleksjonen gjennom bildeteater blir for hver enkelt aktør en fortelling om egen erkjennelsesreise - en utforskende refleksjonsreise som prosessene byr på. Dette kan gi ny innsikt og kunnskap som fremmer forståelsen for kompleksiteten i enhver relasjonell samhandling, og viser enkeltindividets betydning for konstruktiv og god samhandling med andre. Å bli sett og hørt, tatt på alvor og respektert som likeverdige i et samspill, er avgiørende viktig i menneskenes liv, og for deres tilstedeværelse og ytelse i samfunnet. I et kunstpedagogiske perspektiv kan den utforskende refleksjonen medvirke i skapende kunstprosesser likesom i enhver samarbeidsprosess.

I denne studien er det erfaringene til ledere i næringslivet som har vært i fokus, og forskning innen organisasjon og ledelse viser at et godt arbeidsmiljø tuftet på respekt, trivsel og god samhandling gir klare positive resultater på arbeidstakernes ytelsesevne og vilje. For studentene i studiet Bedriftskultur $i$ endring og utvikling, ble den praktiske og utforskende refleksjonsformen et bidrag til ny kunnskap som ga dem en ny plattform å stå på. Studentene etablerte nye perspektiver på verdier og holdninger for samhandling og samarbeid, for enkeltindividets betydning $i$ en organisatorisk setting, samt erfarte viktigheten av åpenhet, raushet, tillit og trygghet gjennom gjensidig respekt.

Studiens undersøkelse av den utforskende refleksjonsformen som en refleksjon i 2. orden, gir inspirasjon til å følge opp med spørsmålet: Kan kroppslig-affektiv refleksjon i en kunstnerisk uttrykksform anses som refleksjon i 3. orden, gjennom innføring av det fysisk sansbare elementet?

Dramapedagogisk historie gjennom flere tiår viser til teaterpraktikere og dramapedagoger og deres utforskende arbeid gjennom kroppslige arbeidsformer (Braanaas, 2008). Som en av disse, kan bildeteater bidra til kunnskapsproduksjon gjennom en kroppslig-affektiv og kritisk kognitiv refleksjon for å belyse en aktuell problemstilling. 
Bildeteater vil gjennom sin fysiske og kroppslige form gi en ekstra dimensjon til refleksjonen; den sansbare erkjennelsen - en mulig aha-opplevelse. Arbeidsformen gir mulighet til å undersøke reelle og iscenesatte konfliktsituasjoner der den kritiskreflekterende granskningen kan bidra til endrings- og utviklingsprosesser. Den kritiske refleksjonen gjennom kunstformen bildeteater kan være et betydningsfullt bidrag til en nyansering av problemstillinger, oppfatninger og opplevelser som i utgangspunktet er emosjonelle og subjektive. Situasjoners/konflikters kompleksitet fremstår tydelig i den kroppslige arbeidsprosessen og gir deltakerne en kroppslig-affektiv fundert opplevelse av den.

\section{Forfatteromtale}

Linda Wilhelmsen er universitetslektor i drama og teater ved UiT - Norges arktiske universitet. Ved siden av sin undervisningsstilling har hun siden 2006 vært engasjert i utviklings-, undervisnings- og forskningsprosjekter i næringslivet, der hun kobler dramafaglige arbeidsformer mot teoretisk perspektiver innen organisasjon, organisasjonspsykologi og ledelsesfag. Hensikten er å skape utvidet forståelse og dypere bevisstgjøring som grunnlag for god ytelse og læring.

\section{Referanser}

Andersen, S. (1997). Case-studier og generalisering. Bergen: Fagbokforlaget.

Argyris, C. (1992). On organizational learning. Massachusetts, USA: Blackwell Publishers.

Boal, A. (1985). Stop! Det er magisk! Gråsten: Forlaget Drama.

Boal, A. (2003). SPIL! Øvelser og lege for skuespillere og medspillere. Gråsten: Forlaget Drama.

Bohm, D. (2010). Om dialog. Fagernes: Flux forlag.

Braanaas, N. (2008). Dramapedagogisk historie og teori. Trondheim: Tapir Akademiske forlag. (4. utgave).

Czarniawska, B. (2004). Narratives in Social Science Research. Introducing Qualitative Methods. London: SAGE Publications.

Engelstad, A. (2001). De undertryktes teater. Når tilskueren blir deltaker. Augusto Boals metoder og praksis. Oslo: Cappelen akademisk forlag.

Freire, P. (1968/2011). De undertryktes pedagogikk. Oslo: Gyldendal Akademiske. (Oversatt av Sissel Lie. Først utgitt på portugisisk år 1968).

Illeris, K. (2013). Transformativ lcering E identitet. Frederiksberg: Samfundslitteratur.

Jakobsen, D. I. (2009). Organisasjonsendring og endringsledelse. Bergen: Fagbokforlaget.

Justesen, L., \& Mik-Meyer, N. (2010). Kvalitative metoder i organisations- og ledelsesstudier. København: Hans Reitzels forlag.

Kaufmann, G., \& Kaufmann, A. (2013). Psykologi i organisasjon og ledelse. Bergen: Fagbokforlaget.

Kvale, S., \& Brinkman, S. (2010). Det kvalitative forskningsintervju. Oslo: Gyldendal Akademiske.

Methi, J. S. (2015). Fortelling som erkjennelsesform. I J. McGuirk, \& J. S. Methi (Red.), Praktisk kunnskap som profesjonsforskning (125-147). Bergen: Fagbokforlaget.

Mezirow, J. (2007). Transformativ læring - overblikk, svar på kritikk, nye perspektiver. I K. Illeris (Red.), Laringsteorier (s. 111-133). Danmark: Roskilde Universitetsforlag.

Platz-Waury, E. (1992). Drama og teater. Oslo: Ad Notam forlag.

Postholm, M. B. (2005). Kvalitativ metode. En innføring med fokus på fenomenologi, etnografi og kasusstudier. Oslo: Universitetsforlaget.

Tønnessen, E. S., \& Bjorvand, A. M. (2014). Teoretiske perspektiver på tekster, medier og lesere. I E. S. Tønnessen (Red.), fakten på fortellinger. Barne- og ungdomslitteratur på tvers av medier (s. 39-65). Oslo: Universitetsforlaget. 


\section{Wilhelmsen}

Wackerhausen, S. (2015). Erfaringsrom, handlingsbåren kunnskap og refleksjon. I J. McGuirk, \& J. S. Methi, (Red.), Praktisk kunnskap som profesjonsforskning (s. 81-100). Oslo: Fagbokforlaget.

Wilhelmsen, L. (2010). Bedriftskultur $i$ endring og utvikling. Fra teori - til bevisstgjøring - til handling. En erfaringsbasert laringsprosess. Forskningsrapport, UiT-Norges arktiske universitet.

Wilhelmsen, L. (2017). Fortellinger på arbeidsplassen - en narrativ tilnærming til personlig utvikling $\mathrm{i}$ en organisatorisk kontekst. I A. Sæbø, S. Eriksson, \& T. Allern (Red.), Drama, teater og demokrati. Antologi I. I barnehage, skole, museum og høyere utdanning (s. 255-269). Bergen: Fagbokforlaget.

The publication charges for this article have been funded by a grant from the publication fund of UiT The Arctic University of Norway 